\title{
プラズマ処理効果の持続性
}

\author{
入山裕 \\ 山梨大学教育人間科学部ソフトサイエンス講座 恶 400-8510 山梨県甲府市武田 4-4-37
}

(2007 年 5 月 10 日受理)

\section{Lasting Effect of Plasma-Treated Surfaces}

\author{
Yu IRIYAMA \\ Division of Interdisciplinary Sciences, University of Yamanashi \\ 4-4-37 Takeda, Kofu, Yamanashi 400-8510
}

(Received May 10, 2007)

\begin{abstract}
Plasma-surface treatment is a technique to treat surfaces of various materials for a wide variety of applications. However, it has been often said that the altered nature of the plasma-treated surface does not last long. The reasons for the decay of plasma treated surfaces are considered to be (1) rotation and migration of surface moieties containing functional groups into inside of the material and (2) disappearance of relatively low-molecular-weight substances including weak boundary layer (WBL) formed in the plasma treatment. However, the decay behavior depends on materials nature, plasma condition, storage condition, and so on, and the precise mechanism is still unknown. The decay also occurs on inorganic material surfaces, and some post-reactions take place even on the plasma-polymerized film surfaces. Since plasma-treated surfaces are very thin and possess a number of active sites, a promising method to prevent the decay, at the present stage, may be immobilization of proper polymers on the surface, such as plasma-induced graft polymerization.
\end{abstract}

KEYWORDS : plasma treatment, plasma polymerization, stability, weak boundary layer, rotation of segment

\section{1.は じめに}

各種材料表面の処理技術の一つにプラズマ表面改質が ある。プラズマとは電離した気体のことで，一般的には グロー放電などの放電によって得られ, 被処理物を気相 プラズマ中にさらすことで処理が行われる。プラズマ中 には多くの活性種が存在するが, そのほとんどは透過力 が小さく, 反応はごく表面に限られている。したがっ て，バルクの性質を損なうことなく表面だけを乾式で短 時間で効率よく改質できるというメリットから，プラズ マ表面改質は広く利用されている。さらにプラズマ処理 では，有害廃裹物がほとんど排出されないことや，一般 的な湿式処理と比べて乾燥工程や廃液等の処理が不要な ことから，環境面や省エネにも優れた技術として，近年 は特に見直されつつある。

E-mail : iriyama@yamanashi.ac.jp
しかし, 以前からよく指摘されていることとして，プ ラズマ処理した後, 時間とともに処理効果が減衰すると いう問題がある。例えば，ごく基本的で一般的なプラズ マ表面改質の目的として接着性・付着性の向上があり, 処理直後は大きく親水性が改善さていれるが, 処理後放 置しておいた材料では親水性が低減し, 接着・付着強度 の低下により，工場ではクレームにまで発展する事態も 生じている。

この処理効果の減衰が起こる理由としては, 一般に古 くから言われているのは，官能基を含むセグメントが反 転し内部へ潜り込むということであるが，さらに最近は プラズマ照射により表面に生成した WBL（weak boundary layer）のような低分子量物質の消失も重要な側面を 持つと言われている。しかしこれらの理由だけで全てが 説明できるものでもない。また，この問題に関しては断 片的な研究は多くあるものの, 系統的な研究はほとんど なく，滅衰機構は完全には解明されていない。 
本稿では，主にプラズマによる親水性処理後の処理効 果の減衰について, 比較的最近の文献からデー夕を紹介 しながらその原因を総合的に探ると同時に，減衰を防ぐ 方法にも言及する。

\section{2. プラズマ処理効果の減衰}

前節でも述べたように，プラズマ処理効果の滅衰は古 くから指摘されていて，これまでに多くの事例が報告さ れているが ${ }^{1 \sim 7)}$, 現在でも同様の結果が毎年のように数 報報告されている。

Fig. 1 はポリアクリルアミドを $\mathrm{N}_{2}$ プラズマで処理し た後の保存時間と接触角の関係 ${ }^{8}$ を，また Fig. 2 は，グ ラファイトを $\mathrm{O}_{2}$ プラズマで処理した後の, 同様の関 係》を示している。いずれの図も，口が未処理表面の接 触角を示す。

これらの図に限らず，同種の論文に掲載されている図 の減衰傾向は，一見類似しているように見える。しかし 詳細に分析すると減衰挙動は一様ではなく, 材料の種 類, プラズマ処理条件, あるいは保存環境などによって 異なる。

Fig. 1 に関しては, $\mathrm{N}_{2}$ プラズマ处理ではアミノ基等の 官能基の導入は容易ではないが, 表面にラジカルが大量 に生成することが予想され，空気中に取り出したとき， それらが酸素と反応して容易に表面は親水化される。ポ リアクリルアミドはもともと疎水性が非常に高い材料で はないが，処理後放置しておくと容易にその処理効果は 失せて踈水化され，元の性質に近付いている。

Fig. 2 のグラファイトの $\mathrm{O}_{2}$ プラズマ处理でも同様の 傾向は見られ，特にこの著者は初期の接触角上昇を強調 しているが，もともと $112^{\circ}$ あったものが $10^{\circ}$ 程度で平 衡に達しているのであるから，このグラファイトについ ては処理効果の減衰は無視できると結論づけてもよさそ うなものである。

プラズマ処理した表面の処理効果の減衰の分析には, Fig. 1，2 で示した接触角が最も基本的で簡易な評価法 であるが，同時にX 線光電子分光法（XPS）を併用す るのが今では常套手段になっている。Fig. 3 は $\mathrm{O}_{2}$ プラ ズマ処理したポリスチレン（PS）の, 処理後の保存時 間に対して，接触角とともにXPS で測定した表面原子 濃度比 $\mathrm{O} / \mathrm{C}$ を示している ${ }^{10)}$ 。未処理 PS の接触角は $85^{\circ}$, O/C はほほ 0 である。概して, 親水性は酸素濃度に比 例し接触角に反比例する。したがって，接触角と酸素濃 度は正反対の性質を示すので，図からもわかるようにそ れらは上下対称のプロットとなり，接触角という直接的 な物性からも, 表面原子濃度という化学的側面からも, 処理効果の減衰を支持するデー夕となる。この図でも，

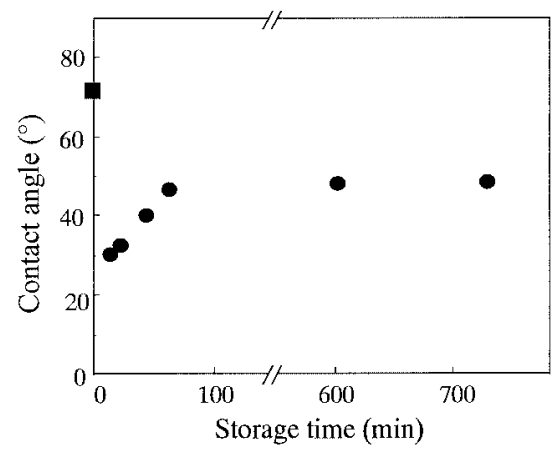

Fig. 1. Contact angle change on the surface of polyacrylamide after $\mathrm{N}_{2}$ plasma treatment as a function of storage time. ${ }^{8)}$

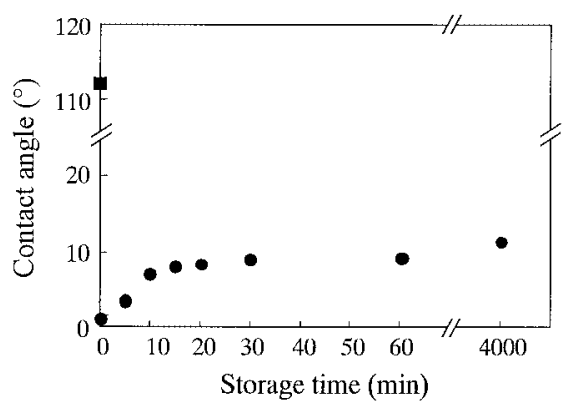

Fig. 2. Contact angle change on the surface of graphite after $\mathrm{O}_{2}$ plasma treatment as a function of storage time. ${ }^{9)}$

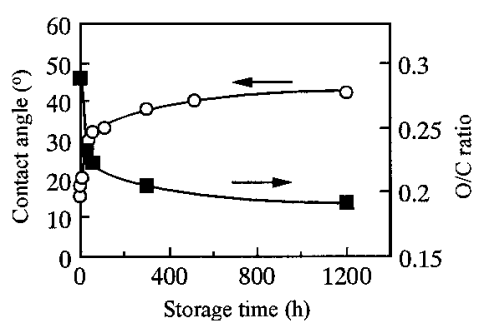

Fig. 3. Changes of contact angle and $\mathrm{O} / \mathrm{C}$ ratio of the surface of polystyrene after $\mathrm{O}_{2}$ plasma treatment as a function of storage time. ${ }^{10)}$

ポリスチレンの処理効果が時間とともに減衰しているの がよくわかる。

\section{3. 無機材料の処理効果の減衰}

有機ポリマー材料では，共有結合の形成や解裂および 回転などで表面の性質が容易に変化することは想像に難 くない。しかし金属あるいは結晶性無機化合物では，有 機材料と同列にそれらを原因として取り扱うことはでき ないので処理効果の減衰機構の解釈は難しいが, 現実に 処理効果は減衰する。

Fig. 2 に示したグラファイトは，炭素だけの共有結合 からなる結晶性の無機化合物とも言える。表面は容易に 


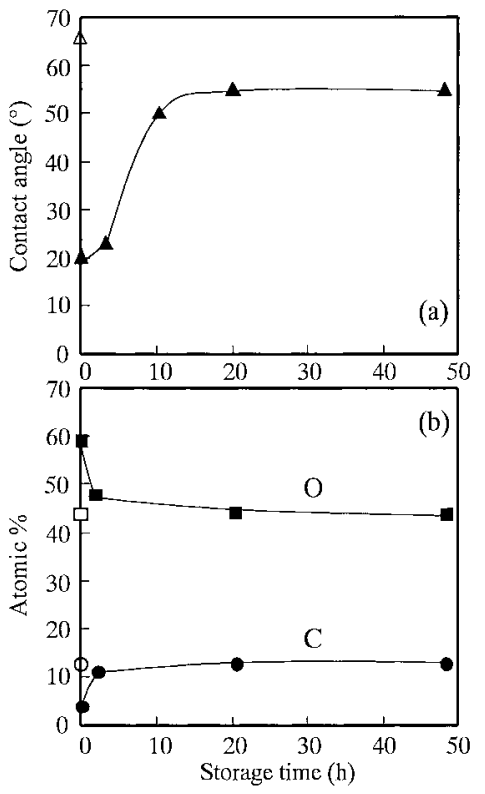

Fig. 4. Changes of (a) contact angle and (b) atomic \% of the surface of ITO after $\mathrm{O}_{2}$ plasma treatment as a function of storage time. ${ }^{11)}$

改質されるが，結晶性であるが故に官能基が回り込みに くいため, 接触角の上昇は小さく処理効果は減衰しにく いと説明づけられる。

Fig. 4 は透明導電膜である ITO（indium tin oxide）を $\mathrm{O}_{2}$ プラズマ処理した後の, 接触角 ( a ) と酸素および 炭素原子濃度（b）の変化を示している ${ }^{11)}$ 。一般に原子 濃度のグラフは Fig. 3 の O/C のように比でとることが 多いが，無機化合物の場合は基準となる炭素がほとんど 含まれないので，そのまま百分率で示すことになる。時 間 $0 \mathrm{~h}$ の中抜きシンボルは未处理 ITO の值である。図か ら明らかなように，この金属酸化物であるITOも，多 くの有機材料と同様にプラズマ処理によって親水化さ れ，その後徐々にその処理効果が減衰している。表面酸 素濃度は，プラズマ処理直後は増加しているが，放置時 間とともに徐々に減少している。炭素濃度と酸素濃度は 全く逆の挙動を示している。この文献にはXPS のスペ クトルとともに仕事関数の変化も示されているが，表面 でどのような反応が起こっているのかを特定するのは容 易ではない。著者らは，プラズマで表面のコンタミが取 り除かれ親水性に変わり，その後またコンタミが起こっ ていると説明しているが，プラズマクリーニングは理解 できても，その後の急速なコンタミ化はにわかには信じ 難い。

Fig. 5 はステンレススチールを大気圧 Ar プラズマで 処理した後，保存したときの（a）接触角，および （b）表面エネルギーの変化を分散項と極性項に分けて 示している ${ }^{12)}$ 。プラズマ処理直後は，接触角は大きく低

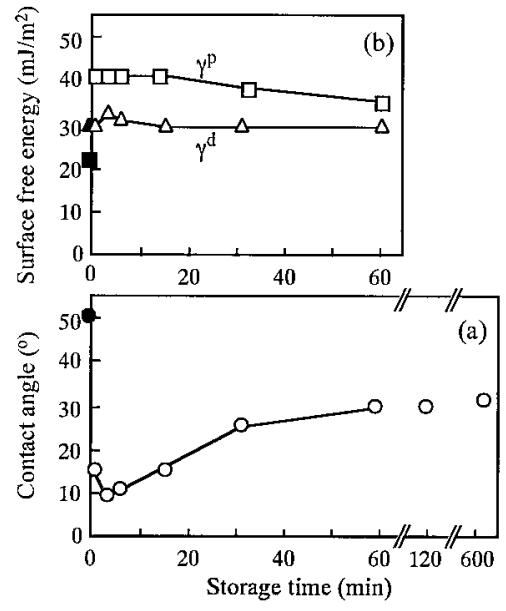

Fig. 5. Changes of (a) contact angle and (b) surface free energy of the surface of stainless steel after Ar plasma treatment as a function of storage time. ${ }^{12)} \gamma^{\mathrm{d}}$ and $\gamma^{\mathrm{p}}$ denote dispersion and polar components of the surface energy, respectively.

下し，表面エネルギーの極性項（ $\left.\gamma^{\mathrm{p}}\right)$ は増加しているが 分散項 $\left(\gamma^{\mathrm{d}}\right)$ はほとんど変化していない。保存初期にお いては接触角がわずかに減少し，表面エネルギーの分散 項が増加している。それは表面が空気中の酸素と反応し 極性官能基が生成しているためと著者らは説明してい る。その後の変化は, 接触角は単調に $30^{\circ}$ 程度まで増加 するのに対し，表面エネルギーについては極性項のみが わずかに減少している。これだけのデータから表面での 反応の特定は難しいが，著者らは表面の不働態化の進行 が影響していると推測している。

\section{4. 紫外線処理との比較}

これまでプラズマ処理により付与された機能・効果は 減衰するものだという定説に基づいて議論を進めている が，果たして「プラズマ処理」であるが故に処理効果が 落ちるのであろうか。プラズマそのものが問題なのであ ろうか。

Fig. 6 は大気圧グロー放電と真空紫外線で処理したポ リプロピレン（PP）の表面エネルギーの変化を比較し ている ${ }^{13)}$ 。図中の数字は印加エネルギーを示している。 未处理 PP の表面エネルギーは○で示すように $28 \mathrm{mN} / \mathrm{m}$ である。また，処理ガスは大気圧グロー放電が $\mathrm{N}_{2}$ で, 真空紫外が $\mathrm{NH}_{3}$ ということで異なり, 厳密な比較はで きないが，接触角の変化には同様の傾向が見られる。す なわち, どちらの处理でも処理直後に表面エネルギーは 上昇し, それが保存時間とともに同程度の速度で減少し ている。

表面処理においては「プラズマ処理では処理効果が減 衰する」との共通認識があるのが事実であるが，実際は 


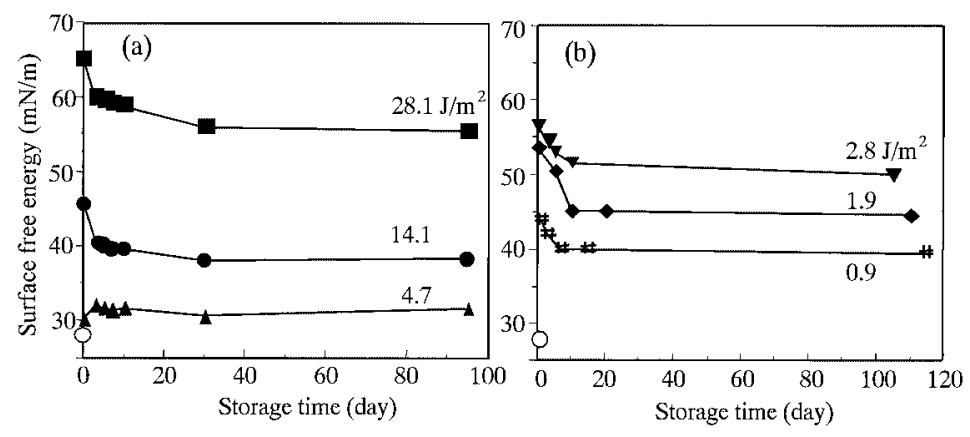

Fig. 6. Comparison of surface free energy change on PP surface with storage time after treatments by (a) $\mathrm{N}_{2}$ atmospheric-pressure glow discharge and (b) $\mathrm{NH}_{3}$ vacuum UV. ${ }^{13)}$ Numbers in the figures denote input energy in the treatments.

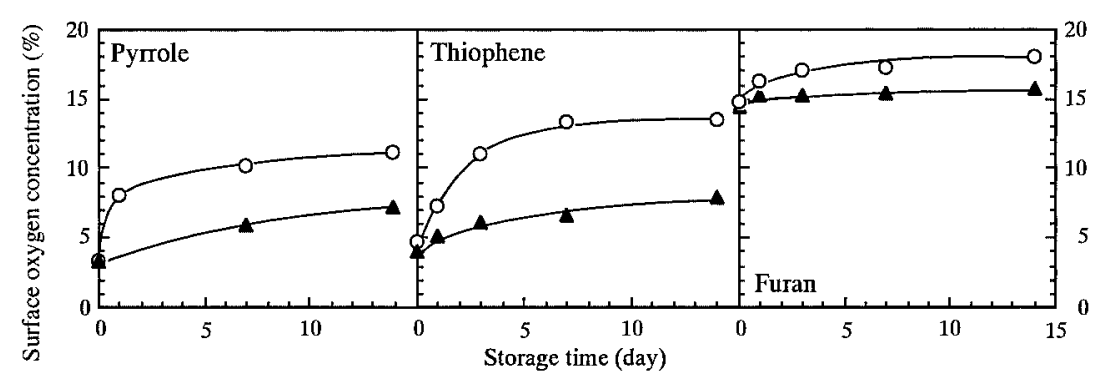

Fig. 7. Surface oxygen concentration change of plasma-polymerized pyrrole, thiophene, and furan films as a function of storage time in air $(\bigcirc)$ and desiccator $(\boldsymbol{\Delta}){ }^{14)}$

プラズマに問題があるのではなく，バルクに影響を与え ることなくごく表層しか処理されないという，プラズマ 処理の代表的な特長が表面の性質を不安定にしているの ではないだろうか。

\section{5. プラズマ重合膜の安定性}

これまで，非重合性ガスのプラズマによる表面処理の 処理効果の減衰を中心に述べてきたが，同様なことは表 面に薄膜を堆積するプラズマ重合にも当てはまる。ただ プラズマ重合の場合は, 基板と全く異なる性質の膜を, ある程度の厚さ堆積するので, 基板表面の官能基が重合 膜を突き破って表面に出ることもなければ, 重合膜が分 解して基板表面の性質が現れることもないので, 表面改 質効果の安定性が問題になることはほとんどない。しか し, 重合直後の重合膜の表面には, 多数のラジカルやダ ングリングボンド，および WBL が存在しており，また 官能基を有するモノマーを用いた場合はその官能基が表 面に残留するであろうし, それらが処理後, 空気中に取 り出したときの酸素などとの反応は非常に複雑で, 決し て表面での変化を無視できるものではない。

Fig. 7 は, 導電性ポリマーの原料（モノマー）である ピロール, チオフェン, およびフランをプラズマ重合し
た後, 空気中およびデシケータ中に放置したときの重合 膜の XPS 分析による表面酸素濃度の変化を示してい る ${ }^{14)}$ 。全ての表面で酸素濃度は増加しているが, その増 加割合は, フランに比べてピロールとチオフェンが, ま たデシケータより空気中に放置したものが大きかった。

さらにピロールのプラズマ重合膜について, 真空デシ ケータでの保存環境も追加して, 表面酸素濃度の増加の 様子を調べた。Fig. 8 に, 空気中と 2 種類のデシケータ で保存し, 途中で保存環境を変化させたときの表面酸素 濃度の変化の様子を示す ${ }^{15)}$ 。通常のデシケータとは, 空 気と等量の酸素を含むが水分は極めて少なく, 真空デシ ケー夕とは, 酸素も水分も非常に少ない環境を意味す る。この図から, 2 種類のデシケータで保存したピロー ル重合膜はほぼ同じ挙動を示し, 空気中に放置したもの と比べて酸素増加は小さい。一般にプラズマ処理した表 面を空気中に取り出すと, まず酸素と反応すると考えら れているが, この実験結果から, ピロールの重合膜は酸 素ではなく, 水と反応していると言える。水と反応して も表面酸素濃度は増加する。おそらくプラズマ重合で, 水と反応しやすい窒素を含む官能基が表面に生成したの であろう。また, 酸素の増加とともに, 窒素の減少も確 認されている。 


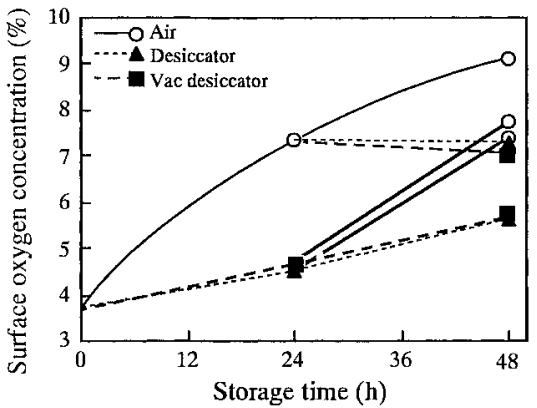

Fig. 8. Change of the surface oxygen concentration of the plasma-polymerized pyrrole films when stored condition is changed. ${ }^{15)}$

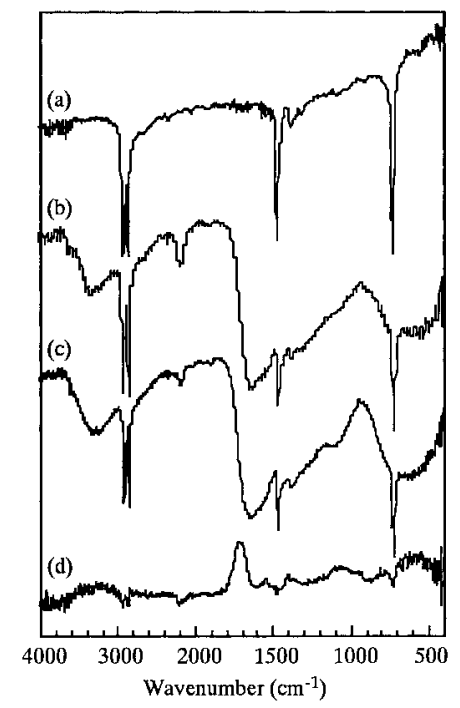

Fig. 9. ATR-FTIR spectra of (a) uncoated LDPE film, (b) plasma-polymerized pyrrole film on LDPE, (c) plasma-polymerized pyrrole film on LDPE after 4week storage, and (d) b-c (difference spectrum). ${ }^{15)}$

Fig.9に未処理の低密度ポリエチレン（LDPE）フィ ルム, LDPE 上に堆積したプラズマ重合直後のピロール 膜，その 4 週間後，およびそれらの差スペクトルとなる ATR-FTIR スペクトルを示す ${ }^{15)}$ 。差スペクトルで, 1720 $\mathrm{cm}^{-1}$ に大きく増加したピークがあるが，それはカルボ キシ基と推定される。すなわち，プラズマ重合により生 成したニトリル基が空気中の水分でゆっくりと加水分解 され，カルボン酸が生成したものと思われる。

表面窒素濃度の急速な減少は, フッ化炭素系の疎水性 材料のアンモニアプラズマ処理でも確認されており ${ }^{16)}$, プラズマにより生成した含窒素官能基は高い反応性を有 する可能性が高い。

\section{WBL の影響}

プラズマ中には多くの活性種が含まれるので, 非重合 性ガスのプラズマであっても表面では多くの反応が進行

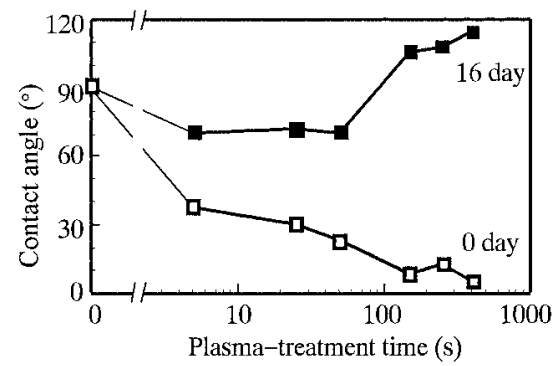

Fig. 10. Relationship between contact angle and Ar-plasma treatment time on HDPE film surface right after the treatment $(\square)$ and after 16-day storage

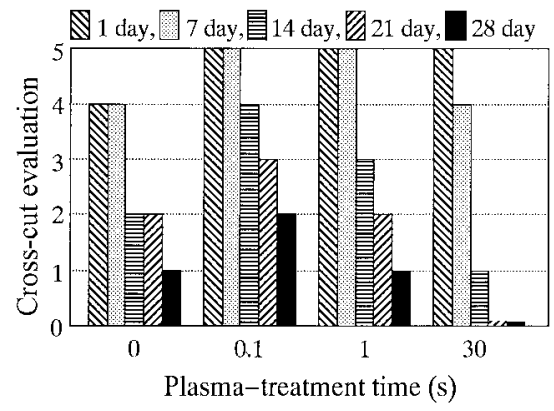

Fig. 11. Relationship between $\mathrm{O}_{2}$ plasma-treatment time of $\mathrm{PC}$ and adhesivity of plasma-polymerized siloxane on the PC for up to 28 day. ${ }^{20)}$

する。プラズマ表面処理で改質された表面の性質とは, それら多くの反応の組み合わせによる結果である。例え ば親水化を目的として，親水化された表面が得られて も，同時にWBL が生成したとすると処理効果の減衰も 進行するであろう。

Fig. 10 は, Ar プラズマ処理した高密度ポリエチレン （HDPE）表面の処理時間と接触角の関係を, 処理直後 と 16 日後で比較している ${ }^{17)}$ 。処理直後では，处理時間 が長いほど接触角は小さい。しかし 16 日後では全ての 試料で接触角は増加しているが，逆に処理時間が長いほ ど増加量は大きく, $100 \mathrm{~s}$ 以上の処理では元の HDPE よ り大きくなっている。この結果だけから結論付けるのは 拙速であるが，長時間の過剩な処理で表面もダメージを 受け，一部分解されてWBL のような低分子量化合物が 表面に生成した可能性は十分ある。低分子量化合物は容 易に蒸発・拡散・脱離しやすく，処理効果を容易に阻害 する。もしそうであれば，長期保存安定性のために，比 較的マイルドで適当なプラズマ処理時間および出力が存 在することも考えられる。しかしまた一方で，今述べた ことと正反対の，長時間処理を支持する報告もあ る $^{18,19)}$ 。

また，論点は少し異なるが処理時間と付着性の関係を 示したデー夕もある。Fig. 11 は, 高周波 $\mathrm{O}_{2}$ プラズマで 
時間を変えて処理したポリカーボネート（PC）にマイ クロ波プラズマで堆積したシロキサンフィルムの, 屋外 暴露時間と付着性の関係を示している ${ }^{20)}$ 。縦軸のクロス カット評価は大きい数值が高い付着性を意味する。PC をプラズマ処理することにより付着性は向上し, 暴露後 1 日と 7 日まではどれも良好な付着性を示しているが, 暴露時間が長くなると, 処理時間が長いものほど付着性 の低下が目立っている。

一般に，プラズマ処理を接着に利用する場合は，処理 直後, 速やかに接着工程に移れば問題はないと考えられ ていたが, 処理効果の低減が単なるセグメントの回転・ 潜り込みではなく, WBL に原因があるとすると, 先に 述べたようにプラズマ处理条件が塗装・印刷後の安定性 に影響を及ぼす可能性も出てくる。また, 過度の処理や 高エネルギー処理は, 表面粗さという別のファクターも 関係してくるので話はさらに複雑になるが, 実際に長時 間処理で接着力が落ちるという報告は多い ${ }^{21233}$ 。

\section{7. プラズマ処理効果の維持}

プラズマ処理効果を維持しようとする試みは多くある ものの, 今のところ, 信頼性が高い方法となると, プラ ズマ開始グラフト重合に行き着く。この方法は, 非重合 性ガスのプラズマで処理して表面にラジカルを形成し, そこにビニルモノマーなどの付加重合性モノマーを接触 させて, 表面からグラフト重合する方法である。目的と する性質（例えば親水性）を持つ分子鎖の長いポリマー を表面に植え付けるので, 基本的にセグメントの潜り込 みは起こらず, WBL も存在しないので, 表面性質は変 化しにくい。

Fig. 12 は，ポリジメチルシロキサン（PDMS）に $\mathrm{O}_{2}$ プラズマ処理したものと, 引き続き2-ヒドロキシエチ ルメタクリレート（HEMA）をグラフトしたものを空気 中に保存したときの接触角の変化を比較している ${ }^{24)}$ 。 $\mathrm{O}_{2}$

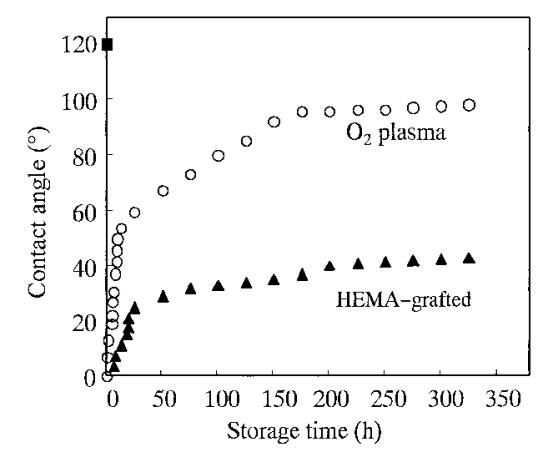

Fig. 12. Contact angle change of the surface of $\mathrm{O}_{2}$ plasma treated PDMS and HEMA-grafted PDMS as a function of storage time. ${ }^{24)}$
プラズマのみでは急速に接触角は上昇し元の PDMS に 近づいているのに対して, HEMAをグラフトしたもの は接触角の上昇が効果的に抑えられているのがわかる。

Fig. 13 は，ポリエチレンテレフタレート $(\mathrm{PET}) / \mathrm{PE}$ 不織布を直流パルス $\mathrm{O}_{2}$ プラズマ処理したものと, 引き 続きアクリル酸（AA）をグラフト重合したものの，O/ $\mathrm{C}$ 比の変化を示している ${ }^{25)} \mathrm{O}_{2}$ プラズマ処理により表 面酸素濃度は非常に高くなるが, 減少率も大きい。しか し， AA をグラフトしたものは，もともと AA の酸素含 有率は一定なのでそれほど $\mathrm{O} / \mathrm{C}$ は高くならないが, 8 か月という長期にわたり, ほとんど変化せず初期の值を 保っている。

Kuzuya らは，プラズマ開始重合とは異なるが，ナイ ロン表面にマレイン酸無水物とメチルビニルエーテルと の共重合体（VEMA あるいは GANTREZ）を含浸させ た後, 高周波 Ar プラズマを照射してナイロン表面を架 橋させながら VEMA を固定化している ${ }^{26,27)}$ 。その後プ ラズマ反応器から取り出し, ナイロンフィルム表面に固

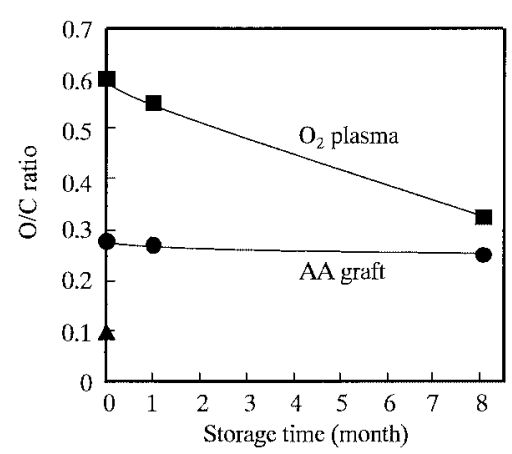

Fig. 13. $\mathrm{O} / \mathrm{C}$ ratio change of the surface of $\mathrm{O}_{2}$ plasma treated and AA-grafted PET/PE nonwoven fabrics as a function of storage time. ${ }^{25)}$

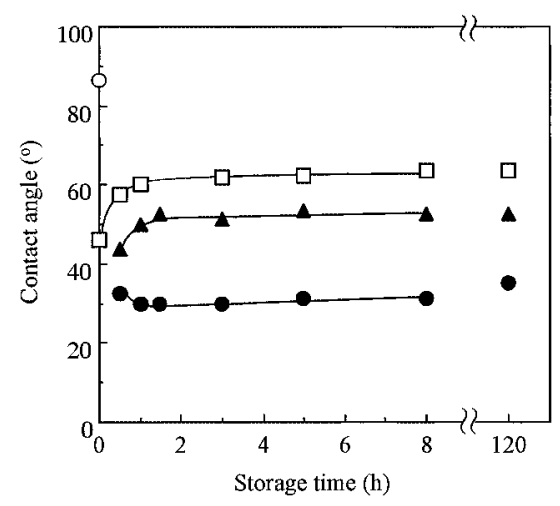

Fig. 14. Contact angle change of the surface of VEMAimmobilized nylon-12 as a function of storage time. ${ }^{26)} \bigcirc$, Untreated nylon; $\square, \mathrm{O}_{2}$ plasmatreated nylon; $\boldsymbol{\Delta}$, VEMA-adsorbed nylon; VEMA-adsorbed and Ar plasma-treated nylon. 


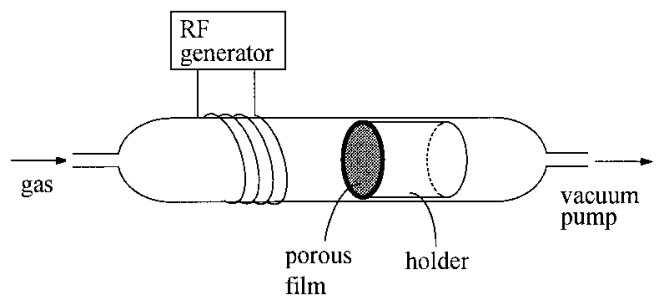

Fig. 15. Plasma reactor for porous films. ${ }^{28)}$

定化されたVEMA のマレイン酸無水物部分を加水分解 することで, 表面にカルボキシル基を有する親水性フィ ルムを得ている。ナイロン表面が架橋しているのでセグ メントの反転が制限され，常に良好な親水性が維持され ると考えられる。Fig.14 は, 長時間保存したときの表 面接触角を, $\mathrm{O}_{2}$ プラズマのみ, VEMA 含浸のみ, VEMA 含浸後 Ar プラズマ処理したナイロンで比較した

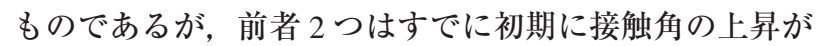
見られるが, VEMA 含浸 $+\mathrm{Ar}$ プラズマでは $120 \mathrm{~h}$ 後も ほとんど変化なく低い值を維持している。この方法はプ ラズマで直接親水性官能基を作り出すのではなく, 少し 手間はかかるが，既に親水性基を持つポリマーを利用す るので，表面にポリマーを確実に固定化できれば信頼性 は高い。

最後に少し趣は異なるが, 多孔膜の表面処理で, 長期 間安定な親水性化を達成している例を紹介する。用いた 膜は限外滤過用のポリスルホン多孔膜（孔径 $1 \mathrm{~mm}$ 前 後）で，特にセグメントの反転を防ぐような固定化など の努力をしたわけではないが, 反応器および被処理膜の 設置法に工夫が見られる。Fig. 15 に，用いられたチュ ーブ型の反応器を示す ${ }^{28)}$ 。プラズマゾーンの下流に, 反 応器の断面方向に被処理物であるポリスルホン多孔膜を 広げて設置している。プラズマは，水を処理ガスとして 誘導結合方式で発生させ，プラズマ中で生成した活性種 を含むガスがポリスルホン膜の細孔を確実に通過するよ うになっている。その結果, 処理したポリスルホン多孔 膜の親水性は長期間にわたって持続され, 水の接触角は 16 か月後も測定できないほど需れ性はよかった。なぜ 処理効果が長期間持続するのかは完全には説明できない が，細孔の奥の隅々まで十分に処理されていることが長 期安定性につながっているのではないかと思われる。こ の方法は多孔性フィルムの被処理物に限られるが, 最も 単純なプラズマ装置で害行可能である。

\section{8. 終わりに}

プラズマ処理効果が減衰する理由はある程度は理解さ れているが, 完全には解明されていない。材料の種類が 変われば, 当然, 減衰挙動は異なる。材料が同じでもプ
ラズマ処理条件が変われば，改質された表面の分子構造 も異なり, 減衰挙動も一様ではない。減衰機構を模索す る上での試みとして, 例えば同じ組成で結晶化度が異な るポリマー材料や，類似した構造で $\mathrm{T}_{\mathrm{g}}$ が異なるポリマ 一材料などを比較する系統的な研究も必要であろう。

しかし, 仮に処理効果減衰の理由が突き止められたと しても，それは単純なプラズマ处理で減衰を阻止するこ とを保証するものではない。前節で述べたように，解決 策は，グラフトするなど物理的に固定化する方法に限ら れてくるのではないだろうか。

プラズマ処理表面を接着・印刷・塗装に利用する上で は, 親水性環境での低温保存, および保存時間の短縮と いった基本は常に意識されるべきである。

\section{文献}

1) X. Xie, T. R. Gengenbach and H. J. Griesser : J. Adhes. Sci. Thchnol. 6, 1411 (1992).

2) S. Carlotti and A. Mas : J. Appl. Polym. Sci. 69, 2321 (1998).

3) T. Murakami, S. Kuroda and Z. Osawa : J. Colloid Interface Sci. 202, 37 (1998).

4) S.-G. Lee, T.-J. Kang and T.-H. Yoon: J. Adhes. Sci. Technol. 12, 731 (1998).

5) C. K. Cho, B. K. Kim, K. Cho and C. E. Park : J. Adhes. Sci. Technol. 14, 1071 (2000).

6) R. W. Paynter : Surf. Interface Anal. 33, 14 (2002).

7) L. Carrino, W. Polini and R. Sorrentino : J. Mater. Proc. Technol. 153/154, 519 (2004).

8) Z. Chen, X. Lu, C.-M. Chan and Y. Mi : Eur. Polym. J. 42, 2914 (2006).

9) U. Cvelbar, B. Markoli, I. Poberaj, A. Zalar, L. Kosec and S. Spaić : Appl. Surf. Sci. 253, 1861 (2006).

10) J. Larrieu, B. Held, H. Martinez and Y. Tison : Surf. Coat. Technol. 200, 2310 (2005).

11) Z. Z. You and J. Y. Dong: Appl. Surf. Sci. 249, 271 (2005)

12) S. Tang, O.-J. Kwon, N. Lu and H.-S. Choi : Surf. Coat. Technol. 195, 298 (2005).

13) F. Truica-Marasescu, S. Guimond, P. Jedrzejowski and M. R. Wertheimer : Nucl. Instrum. Methods Phys. Res. B 236, 117 (2005).

14) Y. Iriyama : J. Photopolym. Sci. Technol. 14, 105 (2001).

15) Y. Iriyama and M. Hanawa : Polym. J. 33, 419 (2001).

16) T. R. Gengenbach, X. Xie, R. C. Chatelier and H. J. Griesser : J. Adhes. Sci. Thchnol. 8, 305 (1994).

17) V. Svorcik, K. Kolarova, P. Slepicka, A. Mackova, M. Novotna and V. Hnatowicz: Polym. Degradation Stab. 96, 1219 (2006).

18) P. P. Tsai, J. R. Roth and W. W. Chen : Text. Res. J. 75, 819 (2005).

19) M. R. Sanchis, V. Blanes, M. Blanes, D. Garcia and R. Balart : Eur. Polym. J. 42, 1558 (2006).

20) B. W. Muir, H. Thissen, G. P. Simon, P. J. Murphy and H. 
J. Griesser : Thin Solid Films 500, 34 (2006).

21) N. Inagaki, S. Tasaka and K. Hibi : J. Adhes. Sci. Technol. 8, 395 (1994).

22) J. Friedrich, L. Wigant, W. Unger, A. Lippitz and H. Wittrich : Surf. Coat. Technol. 98, 879 (1998).

23) K. E. Atkinson and C. Kiely : Compos. Sci. Technol. 58, 1917 (1998).

24) D. Bodas and C. Khan-Malek : Sens. Actuators B 123, 368 (2007).
25) J.-P. Chen and Y.-P. Chiang : J. Membr. Sci. 270, 212 (2006).

26) M. Kuzuya, T. Sawa, T. Yamashiro, S. Kondo and O. Takai : J. Photopolym. Sci. Technol. 14, 87 (2001).

27) Y. Sasai, S. Kondo, Y. Yamauchi and M. Kuzuya : J. Photopolym. Sci. Technol. 19, 265 (2006).

28) M. L. Steen, L. Hymas, E. D. Havey, N. E. Capps, D. G. Castner and E. R. Fisher : J. Membr. Sci. 188, 97 (2001). 